\title{
Populismo judicial, moralismo e o despre- zo à Constituição: a democracia entre velhos e novos inimigos
}

\author{
Judicial populism, moralism and constitu- \\ tional disregard: when democracy stands be- \\ tween old and new enemies
}

Eneida Desiree Salgado ${ }^{1}$

Resumo: A previsão normativa de um Estado de Direito no Brasil é negada cotidianamente. Os mecanismos de controles recíprocos e a garantia de aplicação das regras jurídicas apresentam falhas, em franca negação à supremacia constitucional. Um novo agente de ataque ao constitucionalismo surge: o Poder Judiciário que atua segundo a moralidade subjetiva de seus agentes. O populismo, um inimigo íntimo da democracia, passa a ser protagonizado pelos magistrados, que ignoram as normas jurídicas para decidir sobre o que é justo. Decisões judiciais recentes evidenciam o argumento: usa-se a gramática da exceção para permitir que magistrados atuem para além do Direito em nome do interesse público ou de sua visão

1 Doutora em Direito do Estado. Professora de Direito Constitucional e Direito Eleitoral da Universidade Federal do Paraná. Pesquisadora líder do Núcleo de Investigações Constitucionais. Coordenadora do Politíca Por/De/Para Mulheres. E-mail: desisalg@gmail.com 
perfeccionista e até para restringir prerrogativas de agentes públicos eleitos democraticamente. $\mathrm{O}$ mesmo ocorre com o controle abstrato de constitucionalidade, com a suspensão de Emenda Constitucional por decisão monocrática sem fundamento jurídico e com o apelo a uma fictícia origem democrática de uma lei que ofende diretamente a Constituição - as normas constitucionais tornam-se irrelevantes. Um Estado de Direito não combina com heróis, ainda que togados: falta modéstia ao Poder Judiciário no cumprimento de sua função constitucional.

Palavras-chave: Estado de Direito; Democracia; Poder Judiciário; Controle de Constitucionalidade; Populismo judicial.

Abstract: The constitutional provisions that ensure the Rule of Law in Brazil are constantly denied. Despite constitutional supremacy, tools of mutual control and the safeguards of rights are defective. A new threat for constitutionalism arises: a judicial branch that encroaches upon the Law as if it were merely advancing moral values. Populism - an old enemy of democracy - presents itself as a new friend of judges, who often disregard explicit rules so they can "decide fairly". This argument is certified by recent judicial rulings that often take hold of a "language of exception" that authorizes judges to go beyond Law's boundaries in the name of the public's best interest or even in order to restrict democratically elected officials' rights and prerogatives. The same phenomenon can be witnessed when it comes to judicial review, when a single judge is authorized to temporarily withdraw a constitutional amendment or even when one starts to cherish a fabricated and supposedly democratic law that directly violates the Constitution - as a result, the constitutional articles in Brazil become irrelevant. The 
Rule of Law opens up no space for heroes, even those in robes. The judicial branch is lacking restraint when it comes to comply with its constitutional duties.

Descriptors: Rule of Law; Democracy; Judicial Branch; Judicial Review; Judicial Populism.

\section{Introdução}

A democracia no Brasil parece sempre instável. A garantia dos direitos fundamentais, a separação dos poderes, a Constituição como referência não têm sido características constantes na prática jurídica e política nacionais. De igual forma, os fundamentos do Estado de Direito - mesmo os de caráter liberal, vinculados mais fortemente a uma omissão estatal -vem sendo fragilizados, excetuados, olvidados por uma nova forma de populismo.

O ponto central da discussão aqui travada é a utilização da gramática populista pelos membros do Poder Judiciário e a demonstração como isso ameaça os direitos fundamentais e a democracia. A denúncia deste novo inimigo responde a uma timidez nas análises das atuações dos magistrados para além de suas funções constitucionalmente determinadas, consequência de uma modesta aproximação crítica da teoria jurídica em face das decisões judiciais. Em tempos de instabilidade institucional e descrença nas soluções políticas, apontar as falhas e os problemas dos que se afirmam salvadores no naufrágio implica uma tomada de posição contra as soluções que contrariam o Direito para fazer justiça ou que suspendem a legalidade para a proteção da moralidade tal qual compreendida pela reflexão individual do antes menos perigoso dos poderes. 
Uma abordagem inicial dos elementos do Estado de Direito no plano teórico é combinada com a especificação do Estado brasileiro constituído e instituído em 1988. Combinam-se aportes de teoria do Estado e de Direito Constitucional com dispositivos constitucionais para evidenciar o desenho das competências dos órgãos de soberania e suas bases de legitimação, bem como os limites de seus agentes no cumprimento de suas tarefas. Esta abordagem é acompanhada de uma ligeira teorização sobre os direitos fundamentais, necessária para ressaltar sua compreensão constitucional e doutrinariamente estabelecida como limites à atuação dos agentes públicos.

Logo, a questão do uso da moralidade e da linguagem populista pelos magistrados é enfrentada, com a utilização de aportes teóricos sobre o fenômeno do populismo como ameaça às democracias. As características do discurso, seus elementos e seu substrato são demonstrados para então evidenciar sua presença na retórica judicial, em decisões do Supremo Tribunal Federal em sede de controle de constitucionalidade e em face do controle da Administração Pública. Os elementos de excepcionalidade e o apelo à opinião pública, além da centralidade dos argumentos morais subjetivos em decisões relevantes para a política, corroboram o argumento central aqui apresentado, principalmente quando o objeto do ataque é um poder constituído legitimado democraticamente. Problematiza-se assim a independência judicial em face da lei travestida de ativismo bem-intencionado.

Por fim, conclui-se com a defesa de um Poder Judiciário que atue em defesa dos direitos fundamentais, da democracia, da legalidade e da moralidade nos limites constitucionalmente postos. 


\section{Para que se fale em Estado de Direito: Direito e direitos, poder e poderes}

O Brasil é um Estado de Direito. Um Estado de Direito que, na vida concreta, é excludente, parcial e seletivo, e não alcança a todos: quem escapa do padrão do sujeito racional transcendental muito bem representado politicamente (homem, branco, proprietário, heterossexual, cis e cristão) não tem toda (às vezes nenhuma) proteção do Direito ou do Estado. ${ }^{2}$

No campo normativo, porém, a Constituição estabelece em seu artigo $1^{\circ}$ que a República Federativa do Brasil se constitui em Estado de Direito. A ideia - ou a promessa - do Estado de Direito vem, usualmente, vinculada a algumas premissas. Seu "horizonte de sentido", conforme estabelece Pietro Costa, parte de três pontos cardeais: "o poder político (a soberania, o Estado), o direito (o direito objetivo, as normas), os indivíduos", em uma relação que leve ao fortalecimento da posição dos sujeitos. ${ }^{3} \mathrm{O}$ direito, produzido pelo poder político, serve de barreira ao poder político que ameaça os indivíduos - essa lógica um tanto quanto peculiar da noção do Estado de Direito.

Ao agregar-se à fórmula o adjetivo "democrático" (constante no preâmbulo e também no artigo $1^{\circ}$ da Constituição), mais exigente torna-se a promessa. Esse direito produzido pelo poder para garantir os indivíduos do abuso do poder deve ser, simultaneamente, produzido com o consentimento dos cidadãos, conforme os valores democráticos compartilhados, aplicado segundo o Direito, nos limites do Direito e pelas formas do Direito, e por agentes públicos

2 SOUZA, 2017.

3 COSTA, 2006, p. 96. 
legitimados, direta ou indiretamente, por uma decisão popular. Na compreensão normativa, o consentimento tem que ser periódico, em consultas públicas ou pela representação política, e constante, pelo acompanhamento da atuação dos poderes, pela responsabilidade dos agentes, pela transparência ativa e pelo direito à informação. ${ }^{4}$

Ainda apegada a uma vertente doutrinária, os Estados de Direito, principalmente os de cunho democrático, também se submetem à supremacia da Constituição. A noção de constitucionalismo implica que toda a produção, aplicação e justificação do direito, bem como o atuar dos agentes públicos, ocorram em consonância com a forma constitucionalmente determinada e com seu conteúdo substancial. O constitucionalismo também traz consigo a intenção de racionalizar o poder e de domesticar a força, fazendo com que a sociedade saiba, antecipadamente, de que maneira e até onde podem atuar os agentes públicos e os particulares.

Desta forma, a lógica do Estado Constitucional e Democrático de Direito enreda uma série de mecanismos institucionais para se fazer funcionar. Um sistema de separação de poderes, de freios e contrapesos, de controles recíprocos é parte essencial de sua engenharia. Cada um dos órgãos de soberania, em um sistema racional, age de acordo com a sua função e, por força do constitucionalismo, nos limites de suas competências constitucionais. Ainda, em face da democracia, a atuação dos agentes públicos não pode escapar das regras construídas democraticamente, por meio da representação política em sua atuação respeitosa à supremacia formal e material da Constituição.

Neste ponto particular, vale ressaltar que a construção e reconstrução do ordenamento jurídico e, limitadamente, da própria Constituição, é tarefa do Poder Legislativo, cuja

4 SALGADO, 2015, p. 3. 
legitimidade democrática direta e fundada na representação plural deriva da Constituição e do sistema de recrutamento e nomeação. Apenas ao Poder Legislativo, nos limites e nos termos estabelecidos pelo texto constitucional, é dado aprimorar o sistema jurídico, sem que lhe seja permitido substituir os valores constitucionais e avançar nas restrições impostas pelo núcleo que dá identidade ao sistema, seja manifestado pelas cláusulas pétreas, seja decorrente dos princípios estruturantes.

O Poder Executivo, cuja chefia também conta com legitimação democrática direta e tempo certo à frente da Administração Pública, tem competência para decidir a maneira de executar as tarefas impostas pela Constituição. Não pode ir contra os objetivos definidos, mas tem certa liberdade para resolver como e, limitadamente, a ordem de prioridades, bem como a estratégia de enfrentamento das demandas. A eleição usualmente reflete qual programa de governo - o "como" - deverá ser executado durante o mandato; a cidadania, em face de distintas opções apresentadas na competição eleitoral, elege a que deve ser executada. Por força de determinação constitucional, os chefes do Poder Executivo escolhem auxiliares para a tarefa de administrar, desde que tenham mais de 21 anos e estejam no exercício dos direitos políticos. Pode parecer que os requisitos constitucionais para a livre nomeação de ministros ou secretários pela chefia do Poder Executivo são demasiados débeis, porém não é dado a agentes públicos "corrigirem" essa frouxidão constitucional.

O Poder Judiciário, por sua vez, não pode decidir nem alterar o "que", nem tem primazia para determinar o "como". ${ }^{5}$ Pode corrigir as decisões dos poderes democraticamente legitimados apenas se suas ações contrariarem a Constituição e, portanto, desafiarem a supremacia constitucional.

5 SÁNCHEZ MORÓN, 1995. 
O Poder Judiciário tem como competência primordial a guarda da Constituição (como decorre de uma leitura singela do artigo 102, e "que não está a estatuir a sua exclusividade na produção do significado constitucional"') e extrai a legitimidade de sua atuação da fidelidade ao ordenamento jurídico. O respeito ao texto normativo é fundamental para a construção da norma que irá resolver o caso concreto. Há primazia do texto constitucional, em decorrência da supremacia da Constituição e da distinção entre poder constituinte e poder constituído na adjudicação. ${ }^{7}$ Além disso, sem autorização constitucional para inovar na ordem jurídica e constitucional, o Poder Judiciário protege as decisões políticas tomadas quando da instituição da democracia constitucional. Por isso há um componente contramajoritário na atuação dos magistrados - em defesa do determinado pela norma constitucional, eventualmente podem afastar decisões tomadas pela maioria democraticamente manifestada.

Assim, a democracia constitucional - à qual, por força de decisão constituinte, estamos vinculados - é "aquele regime (ou forma de governo) em que o exercício do poder de decisão coletiva (fundado na atribuição de direitos políticos a todos os membros adultos da coletividade) se encontra formal e materialmente limitado" ${ }^{8}$ E essas decisões coletivas são o parâmetro para a atuação dos poderes constituídos, submetidos à e domesticados pela Constituição e democracia.

Em um sistema racional de supremacia constitucional democraticamente fundada, os valores que devem comandar a atuação dos agentes públicos (e até os particulares) são aqueles constitucionalmente estabelecidos. Se há alguma moral que possa ser utilizada como vetor para a tomada de

\footnotetext{
6 RESENDE; VIEIRA, 2016, p. 417.

7 MÜLLER, 2010, p. 106.

8 SALAZAR UGARTE, 2006, p. 57.
} 
decisões, é a moral objetivamente plasmada na Constituição, não havendo autorização para fundamentalismos axiológicos para além das decisões constituintes.

Para insistir no óbvio: outro componente indispensável deste Estado são os direitos fundamentais, verdadeiras garantias, trunfos dos cidadãos em face do poder e das decisões das maiorias. ${ }^{9}$ São balizas que permitem a cidadania exercitar sua autonomia pública e privada, também trazendo restrições como resultado da ausência de caráter absoluto em sua configuração.

Os direitos fundamentais são direitos garantidos por um Estado, por meio de uma Constituição ou de uma lei constitucional. Distinguem-se dos direitos humanos por sua fundamentação no direito positivo (e não em um jusnaturalismo metafísico) e por seus destinatários serem os cidadãos daquele Estado - e eventualmente outros que estiverem em seu território. Se em relação aos direitos humanos há uma discussão entre relativistas e universalistas (sobre se a leitura ocidental sobre os direitos humanos devem se aplicar a todos os países e culturas), no tocante aos direitos fundamentais esse debate inexiste no campo normativo - a preocupação maior é com a efetividade dos direitos fundamentais e sua "seletividade" em face dos diferentes estamentos sociais.

A Constituição de um Estado impõe o respeito aos direitos fundamentais por parte dos agentes públicos, sejam eles parlamentares, administradores, burocratas, integrantes das forças de segurança pública, membros do Ministério Público, magistrados, professores. É possível até, em face da eficácia horizontal, afirmar que os particulares devem respeitar os direitos fundamentais nas relações privadas. ${ }^{10}$ As garantias constitucionais do indivíduo contra o poder

9 NOVAIS, 2006. DWORKIN, 2002.

10 SARLET, 2010, p. 127-128. 
devem informar a elaboração do direito, sua aplicação, sua interpretação e sua adjudicação.

A geração de juristas pós-88 tinha isso por garantido, com preocupação concentrada na questão dos direitos sociais. Na política constitucional, a estratégia foi fortalecer o Poder Judiciário para garantir a efetividade dos direitos sociais e do cumprimento dos objetivos fundamentais da República. Contava-se com o Poder Judiciário para cumprir a Constituição e fazer cumprir a Constituição, impondo aos demais poderes o que a decisão constituinte determinava. Não se imaginava que em pleno século XXI haveria ameaças a direitos de liberdade, como a liberdade de expressão, a liberdade de manifestação e a liberdade de cátedra e um desmonte dos direitos coletivos, ao lado de um desprezo pela soberania popular quando o povo escolhe "errado" o seu mandatário. Não havia medo do Poder Judiciário atuar na desconsideração da Constituição, do desprezo às cláusulas pétreas, na assunção de um discurso moralista que despreza direitos políticos, prerrogativas parlamentares e a separação de poderes. Mas é o que está acontecendo.

\section{O novo populismo como inimigo da demo- cracia: o Poder Judiciário e o moralismo no lugar da legalidade}

O respeito amplo aos direitos fundamentais é indiscutível no plano normativo. No mundo do dever ser, a centralidade dos direitos fundamentais em uma democracia é incontestável. No plano dos fatos, no entanto, a democracia e os direitos fundamentais são constantemente ameaçados por inimigos internos e externos e a luta por sua observância e concretização deve ser constante. 
Os inimigos íntimos da democracia - porque gerados em seu interior a partir de seus elementos constitutivos (o povo, a liberdade e o progresso) - apontados por Tzvetan Todorov são o populismo, o ultraliberalismo e o messianismo. "O messianismo, essa política em nome do bem e do justo, prejudica tanto a um quanto a outro". Embora o autor se preocupe com as chamadas "guerras justas", sua descrição parece encaixar-se perfeitamente à dinâmica interna em determinadas sociedades: “A moral e a justiça a serviço da política dos Estados prejudicam a moral e a justiça, porque as convertem em simples instrumentos nas mãos dos poderosos e as fazem aparecer como um véu hipócrita que oculta a defesa de seus interesses". ${ }^{11}$

No contexto brasileiro, o messianismo e o populismo deixaram de ser exclusivos nos espaços de luta eleitoral. O uso do discurso moralista já vai além da tentativa de conquista de votos ou da intenção de macular a imagens de adversários em propagandas e debates. De igual forma, a estratégia de um populismo que confia no "'desencantamento' e desilusão em larga escala na maioria dos partidos políticos pelos eleitores"12 não está nos líderes políticos fundamentalistas apenas. Uma de suas características constantes do populismo é o baixo apreço por controles, por checks and balances sobre sua atuação. Jan-Werner Müller afirma que os populistas não desprezam todas as instituições, mas "apenas se opõem àquelas instituições que, em sua visão, falham em produzir respostas políticas moralmente (em oposição à empiricamente) corretas". ${ }^{13}$

Aqui são outros os inimigos da democracia. O simulacro de Estado de Direito que antes só alcançava os excluídos - negros, pobres e, em determinada medida, mulheres - ago-

11 TODOROV, 2012.

12 PAP; ŚLEDZIŃSKA-SIMON, 2017.

13 MÜLLER, 2017. 
ra atinge níveis comparáveis às rupturas institucionais. ${ }^{14} \mathrm{O}$ estado de exceção uma vez mais parece ter virado regra. A gramática da justificação não se modificou em sua essência: há ecos dos "conflitos ideológicos", o "estado de apreensão criado no País pela infiltração comunista" que exige "remédios, de caráter radical e permanente", a "decomposição das nossas instituições civis e políticas", mencionados em 1937; o ato institucional contra o governo legítimo "que deliberadamente se dispunha a bolchevizar o País", como forma de "assegurar ao novo governo a ser instituído os meios indispensáveis à obra de reconstrução econômica, financeira, política e moral no Brasil, de maneira a poder enfrentar, de modo direto e imediato, os graves e urgentes problemas de que depende a restauração da ordem interna e do prestígio internacional da nossa Pátria" de 1964. Esse discurso continua na boca de alguns políticos saudosos da ditadura e nos editorais de veículos de empresas de comunicação. Agora, no entanto, a origem do discurso é mais plural.

A perda de referência da Constituição para o controle abstrato de constitucionalidade já se mostra na decisão sobre a Lei Ficha Limpa (Lei Complementar no 135/2010), em provocação capitaneada pelo Partido Popular Socialista e pela Ordem dos Advogados do Brasil. Embora não tenha sido respeitado o rito constitucional do processo legislativo (pois houve mudança na casa revisora e o projeto de lei não retornou à Câmara de Deputados) e as novas hipóteses desafiarem diretamente a Constituição e notadamente a teoria dos direitos fundamentais (com interpretação pela aplicação a fatos anteriores e com prazos de restrição sem termo legal) e a Convenção Interamericana de Direitos Humanos (pela possibilidade de impedimento decorrente de decisão de órgão profissional e pela inexigibilidade de trânsito em

14 VALIM, 2017. 
julgado), ${ }^{15}$ a maioria do Supremo Tribunal Federal decidiu validar a lei. Seus principais argumentos foram o pedigree democrático da lei (facilmente recusável face ao procedimento de coleta de assinaturas e ante as emendas durante $o$ processo legislativo) e sua caracterização como o "Estatuto da Ética e da Moralidade da Cidadania Política Brasileira", que deve assim ser interpretado buscando garantir a "proteção dos interesses maiores de toda a coletividade". ${ }^{16}$

Uma liminar concedida no mesmo dia da propositura de uma ação direta de inconstitucionalidade e jamais levada à apreciação do pleno é outro exemplo da total irrelevância das regras constitucionais. Pela Emenda Constitucional $n^{\circ} 73$ foram criados novos Tribunais Regionais Federais. Em tramitação por mais de uma década, a proposta foi aprovada por $72 \%$ dos deputados e $77 \%$ dos senadores e acabou paralisada (há mais de cinco anos) por decisão monocrática do então presidente do Supremo Tribunal Federal. Os argumentos vão desde a existência de demandas mais relevantes até a existência de um pretenso vício de iniciativa, em face da não participação do Poder Judiciário na propositura da reforma constitucional. ${ }^{17} \mathrm{~A}$ irrelevância do dispositivo constitucional é evidente: os incisos do caput do artigo 60 da Constituição, que tratam dos legitimados a propor emenda à Constituição, não incluem o Poder Judiciário. Ainda assim, não há vício na Emenda $n^{\circ} 73$, mas em nome da leitura individual do que deveria ser a Constituição, um ministro a suspendeu até quando outros ministros assim o desejarem.

15 FERREIRA, 2015, p. 200.

16 Supremo Tribunal Federal. Ação Direta de Constitucionalidade $n^{\circ} 29$ e n ${ }^{\circ}$ 30. Voto do Ministro Joaquim Barbosa. Julgamento em 16 de fevereiro de 2012.

17 Supremo Tribunal Federal. Ação Direta de Inconstitucionalidade no 5017. Decisão liminar do Ministro Presidente Joaquim Barbosa em 17 de julho de 2013. 
Em 2016 - sob a Constituição de 1988 e não sob o Ato Institucional $\mathrm{n}^{\circ} 5$ de 1968 - estabeleceu-se, para fins de adjudicação do direito, que casos inéditos escapam "ao regramento genérico, destinado aos casos comuns" e que uma garantia constitucional "pode, em casos excepcionais, ser suplantado pelo interesse geral na administração da justiça e na aplicação da lei penal" ${ }^{18} \mathrm{Na}$ decisão originária, outro magistrado expressamente reconheceu que "a divulgação pública das conversações telefônicas interceptadas, nas circunstâncias em que ocorreu, comprometeu o direito fundamental à garantia de sigilo, que tem assento constitucional" e que "é descabida a invocação do interesse público da divulgação ou a condição de pessoas públicas dos interlocutores atingidos, como se essas autoridades, ou seus interlocutores, estivessem plenamente desprotegidas em sua intimidade e privacidade". No entanto, não vislumbrou indícios de infração administrativa ou penal. Na decisão sobre o recurso, um magistrado decidiu (e fundamentou sua decisão na exceção) que o direito e as garantias constitucionais podem ser suspensos por decisão unilateral de (outro) magistrado, sem previsão constitucional, sem acionamento do sistema constitucional das crises e, portanto, sem seus limites e controles. Pareceu-lhe que o fim do ato do magistrado, a divulgação para os meios de comunicação de conversa telefônica envolvendo a Presidenta da República interceptada após a determinação da interrupção da escuta em processo que tinha outro objeto, apesar de claramente desafiar o ordenamento jurídico, era moralmente desejado e, portanto, os meios deveriam ser moralmente aceitáveis, ainda que contrários à lei e à Constituição.

18 Tribunal Regional Federal da $4^{\mathrm{a}}$ Região. P.A. Corte Especial n ${ }^{\mathrm{o}}$ 00302132.2016.4.04.8000/RS. Voto do Relator Des. Federal Rômulo Pizzolatti. Decisão de 22 de setembro de 2016. Disponível em https://www.conjur.com. br/dl/lava-jato-nao-seguir-regras-casos.pdf. 
A moralidade toma o lugar da Constituição e de legalidade também quanto às faculdades do Presidente da República. A Constituição estabelece que "compete privativamente ao Presidente da República nomear e exonerar os Ministros de Estado" (artigo 84, I), entre brasileiros maiores de vinte e um anos e no exercício dos diretos políticos (artigo 87), sem participação ou autorização dos demais órgãos de soberania. Para anular uma nomeação de um ministro de Estado tida como "imoral", um magistrado considerou existente direito líquido e certo para defesa da ordem institucional no afastamento de "ilícito atípico" fundado em "confissão extrajudicial" extraída de conversa gravada após ordem judicial para suspensão da interceptação e divulgada em nome do interesse público, ${ }^{19}$ aquela mesma divulgação contrária à Constituição e que não trouxe consequências ao magistrado que lhe deu causa. Ilícito atípico é algo que não encontra lugar em um Estado de Direito. O sistema sancionador tem um regime jurídico próprio, que implica na exigência de que as condutas que se consideram ilícita sejam especificamente previstas, no âmbito de uma legalidade estrita. Tudo isso foi ignorado em nome da leitura privada moral do julgador.

Em caso análogo, no entanto, sob outro relator no mesmo Tribunal, manteve-se a nomeação, por outro chefe do Poder Executivo, de cidadão investigado. Neste segundo caso considerou-se que "a nomeação de alguém para o cargo de Ministro de Estado, desde que preenchidos os requisitos previstos no art. 87 da Constituição da República, não configura, por si só, hipótese de desvio de finalidade (que jamais se presume), eis que a prerrogativa de foro - que traduz consequência natural e necessária decorrente da investidura

19 Supremo Tribunal Federal. Medida Cautelar em Mandado de Segurança n 34.070. Ministro Gilmar Mendes. Decisão de 18 de março de 2016. 
no cargo de Ministro de Estado (CF, art. 102, I, “c”) - não importa em obstrução e, muito menos, em paralisação dos atos de investigação criminal ou de persecução penal" ${ }^{20}$ Nada de $u b i$ eadem ratio, ibi idem jus. Nada de direito na razão do Estado.

Duas outras decisões revelam que os representantes políticos, democraticamente eleitos e titulares de um estatuto constitucional próprio, não escapam da sanha moralizadora que suspende a Constituição em nome do bom e do justo (ou o que o julgador assim o considera). Em decisão liminar, determinou-se a prisão de um senador da República. A Constituição determina que "os membros do Congresso Nacional não poderão ser presos, salvo em flagrante de crime inafiançável" (art. $53 \S 2^{\circ}$ ). O texto constitucional estabelece como crimes inafiançáveis a prática de racismo, a prática da tortura, o tráfico ilícito de entorpecentes, o terrorismo e os definidos como crimes hediondos e ainda a ação de grupos armados, civis ou militares, contra a ordem constitucional e o Estado Democrático (art. 50 XLII, XLIII e XLIV). As condutas do senador descritas no processo se referem a embaraço à investigação criminal que envolve organização criminosa e o pedido do Ministério Público traz, implicitamente, a alegação de norma constitucional inconstitucional: “O tom absolutista do preceito proibitivo de prisão cautelar do art. $53, \S 2^{\circ}$, da Constituição da República não se coaduna com o modo de ser do próprio sistema constitucional; se não são absolutos sequer os direitos fundamentais, não faz sentido que seja absoluta a prerrogativa parlamentar de imunidade à prisão cautelar". De maneira explícita, surge a alegação do desvio de finalidade do exercício do mandato e que "a existência de um Judiciário livre, autônomo e independente" implica em não "subtrair do Poder Judiciário, de forma ab-

20 Supremo Tribunal Federal. Medida Cautelar em Mandado de Segurança $\mathrm{n}^{\mathrm{o}}$ 34.609. Ministro Celso de Mello. Decisão de 14 de fevereiro de 2017. 
soluta, medidas cautelares que, por sua natureza, são ínsitas e imprescindíveis ao pleno exercício da jurisdição". Ou seja, em nome de um princípio e de uma leitura moral, pede-se a afastamento de uma regra constitucional - razão definitiva para decidir, segundo a doutrina contemporânea - que garante a existência de um Parlamento livre, autônomo e independente. $\mathrm{O}$ magistrado aponta a presença de elementos do tipo de participação em organização criminosa, crime permanente segundo a jurisprudência do Supremo Tribunal Federal e que, portanto, "contempla não só a possibilidade de flagrante a qualquer tempo", "como até mesmo a chamada 'ação controlada'”. A inafiançabilidade decorreria do art. 324, IV do Código de Processo Penal, sem mais explicações. Teratologicamente, afirma que o crime é inafiançável porque não seria possível conceder fiança "quando presentes os motivos que autorizam a decretação da prisão preventiva". Ou seja, esvazia-se absolutamente a diferenciação constitucional entre crimes afiançáveis e crimes inafiançáveis, sem sequer apresentar argumentação. Por sua vez, o fundamento para o afastamento da regra da imunidade é retirado de decisão anterior ${ }^{21}$ que afirma a não incidência na espécie em face de "condição especial e excepcional, em que a sua aplicação gera a afronta a todos os princípios e regras constitucional que se interligam para garantir a integridade e a unidade do sistema constitucional".22

O mesmo ministro afasta um deputado de seu mandato e de suas funções como presidente da Câmara. A liminar, referendada pela unanimidade dos ministros, parte de um

21 A decisão que serve de base para a prisão do senador é o HC 89417, de relatoria da Ministra Cármen Lúcia, julgado pela Primeira Turma em 22 de agosto de 2006.

22 Supremo Tribunal Federal. Ação cautelar n ${ }^{\circ}$ 4039. Ministro Teori Zavascki. Decisão de 24 de novembro de 2015. 
pedido da Procuradoria-Geral da República, que reconhece que a medida é "grave e excepcional" em face de situação "absolutamente atípica e diferenciada". Novamente se alega que a atuação do parlamentar "atenta contra a ordem pública e contra a liberdade e independência do Poder Judiciário". Na decisão, o ministro afirma inafastável a competência constitucional das casas congressuais de decidir sobre a cassação do mandato dos parlamentares, expressa no artigo $55 \S 2^{\circ}$, mesmo nos casos de condenação criminal com suspensão de direitos políticos. No entanto, afirma o julgador, isso não ocorre durante a persecução penal, que permitiria "afastamentos temporários da função, desde que existam elementos concretos, de particular gravidade, que revelem a indispensabilidade da medida para a hígida sequência dos trabalhos judiciários". A legitimidade das medidas cautelares contra deputados residiria no princípio da inafastabilidade da jurisdição, em "preceitos éticos da maior relevância" e na "equiprimordialidade entre os diferentes poderes constituídos, a partir da consideração dos espaços de fiscalização recíproca entre eles" (embora em sua fundamentação sempre se refira à possibilidade de o Poder Judiciário afastar os agentes públicos, inclusive os magistrados). Assim, seria "inteiramente cabível, por certo que em circunstâncias excepcionais devidamente justificáveis e justificadas, o pedido de afastamento temporário do exercício do mandato parlamentar". Para o ministro - não para a Constituição - a permanência do deputado no Parlamento e na Presidência da Casa seria "um pejorativo que conspiraria contra a própria dignidade da instituição por ele liderada". Novamente a gramática da excepcionalidade é utilizada: "Também o veículo da vontade popular - o mandato - está sujeito a controle. A forma preferencial para que isso ocorra, não há dúvida, é pelas mãos dos próprios 
parlamentares. Mas, em situações de excepcionalidade, em que existam indícios concretos a demonstrar riscos de quebra da respeitabilidade das instituições, é papel do STF atuar para cessá-los, garantindo que tenhamos uma república para os comuns, e não uma comuna de intocáveis". Ao final da decisão, revela a dimensão toda da fundamentação apresentada: "Decide-se aqui uma situação extraordinária, excepcional e, por isso, pontual e individualizada. A sintaxe do direito nunca estará completa na solidão dos textos, nem jamais poderá ser negativada pela imprevisão dos fatos. Pelo contrário, o imponderável é que legitima os avanços civilizatórios endossados pelas mãos da justiça".$^{23}$

Se soberano é o que decide sobre o estado de exceção, ${ }^{24}$ ou por sobre a norma, o Poder Judiciário, ao tomar essas decisões a partir desses fundamentos, ocupa o lugar da Constituição, do ordenamento jurídico, da vontade popular. Ao afastar o Direito posto por sua leitura particular, atuando para além do texto constitucional, com justificativas de excepcionalidade, os magistrados promovem uma quebra das garantias do constitucionalismo e do Estado de Direito. Não é permitido a um dos poderes do Estado, ainda mais aquele sem legitimidade democrática direta, atuar segundo suas próprias crenças e desejos. Não é admissível que o órgão de cúpula do Poder Judiciário se sinta à vontade para "empurrar a história", ou se apresentar como a vanguarda iluminista, ${ }^{25}$ "aperfeiçoando o produto do poder constituinte em nome da moral, da verdade e da justiça." Não é concebível que um agente público alegue ou pressuponha um direito de resistência a uma ordem constitucional insuficiente ou im-

23 Supremo Tribunal Federal. Ação Cautelar n 4070. Voto do relator Ministro Teori Zavascki.

24 SCHMITT, 2009, p. 13.

25 Como perigosamente defende Luis Roberto Barroso (BARROSO, 2015). 
perfeita e exerça a desobediência civil. Como afirma Emerson Gabardo: “Na modernidade, não cabe à autoridade julgar os meios que lhe são postos à disposição pelo sistema jurídico, pois só quem é soberano pode decidir sobre os limites do seu próprio poder. E a soberania, no Estado de Direto, é da Lei e não da autoridade - por mais famosa, importante, rica, sábia, justa, eficiente ou linda que seja a autoridade" ${ }^{\prime 26}$

$\mathrm{O}$ ativismo judicial para além dos limites constitucionais com fundamento em argumentações extrajurídicas sugere que o messianismo e o populismo se deslocaram na estrutura estatal. Se o medo do discurso moral, contrário à Constituição, vinha relacionado com o agir do Poder Executivo e, de maneira mais fraca, do Poder Legislativo e dos partidos políticos, agora a preocupação é com os salvadores da pátria togados.

\section{Conclusão: Mais Ulisses e menos Hércules - as togas contra os direitos fundamentais ou a opinião publicada contra o texto normativo}

Os populistas recusam respostas que não sejam moralmente corretas. E quem se acredita capaz de dar resposta corretas, sejam juridicamente corretas, moralmente corretas, e/ ou politicamente corretas é o Poder Judiciário brasileiro. Talvez inspirados por Dworkin e por uma leitura particular e parcial da alegoria do juiz Hércules, ${ }^{27}$ hoje muitos magistrados (os que mais aparecem) pensam ser semideuses, capazes de melhorar o produto do poder constituinte e aperfeiçoar moralmente a sociedade por decisões justas. Dois proble-

26 GABARDO, 2017.

27 DWORKIN, 2007. Para uma crítica da hermenêutica moral de Dworkin, ver MACHADO, 2014. 
mas de desenho institucional podem ter colaborado para isso: um deles, o mais simples, é a denominação "sistema de administração da justiça". Parece, pela nomenclatura, que os magistrados devem realizar a justiça, ainda que seja contra o Direito, o que não encontra guarida em um Estado Democrático de Direito.

Outro problema é a forma de recrutamento de magistrados, tanto no concurso público como na nomeação. A maneira como é realizado o concurso por vezes faz com que os candidatos ao Poder Judiciário se afastem do mundo da vida e se dediquem a um estudo tecnicista, em uma espiral meritocrática individualista que não percebe o valor de investimento no tempo dedicado ao estudo, usualmente bancado pelos pais e que importa em um forte recorte de classe. Além disso, a aura do recrutamento, pelo esforço considerado puramente pessoal, implica muitas vezes um sentimento de superioridade em relação aos agentes públicos que dependem da competição eleitoral. ${ }^{28}$ Essas duas características combinadas fazem com que muitos membros do Poder Judiciário sejam incapazes de praticar a alteridade, não consigam se colocar nos pés daqueles que julgam e se sintam credores de um agradecimento especial do Estado, o que justificaria inclusive um conjunto de prerrogativas que, concedidas a outro estamento, não passaria em seu próprio teste de moralidade.

Usa-se Hércules indevidamente para defender um poder acima de qualquer suspeita e de qualquer limite. Um uso reverso da alegoria, assim, pois o juiz Hércules só é acionado para casos difíceis, nos quais o ordenamento jurídico não traz uma regra para a resolução do caso concreto e Dworkin nega expressamente a possibilidade de que tal juiz seja ativista. ${ }^{29} \mathrm{E}$

28 REZENDE, 2018.

29 DWORKIN, 2007, p. 474. 
a exigência de um superjuiz é para impor o ônus argumentativo para os julgadores, que devem demonstrar com base em precedentes (impraticável no Brasil) e nas circunstâncias concretas, a construção da resposta correta para o caso.

O Poder Judiciário, no entanto, por vezes ignora a regra para aplicar a moralidade. Vira Hércules sem necessidade, e, ao arrepio do texto normativo, assume excetuar a ordem jurídica para atender a opinião pretensamente pública. A figura do herói usa capa. Preta. E enquanto isso, na Sala de Justiça, a Constituição é rasgada em nome da sociedade. Falta-lhe a auto-restrição do herói modesto, de Ulisses, de respeito ao poder constituinte, à vontade popular positivada em normas jurídicas, de consideração do princípio da conformidade funcional.

Assim, se espera uma modéstia judicial - que os magistrados se amarrem no mastro do constitucionalismo e não sucumbam ao canto das sereias da opinião pública, que deseja espetáculos e heróis. Que incorporem as promessas constitucionais de democracia e república. ${ }^{30} \mathrm{Ou}$ que, de uma vez, se coloque uma toga no lugar da Constituição.

30 SALGADO, 2017. 


\section{Referências bibliográficas}

BARROSO, Luis Roberto. A razão sem voto: o Supremo Tribunal Federal e o governo da maioria. Revista Brasileira de Políticas Públicas. Vol. 5, número especial, 2015.

COSTA, Pietro. O Estado de Direito: uma introdução histórica. In: COSTA, Pietro; ZOLO, Danilo (orgs). O Estado de Direito. História, teoria, crítica. São Paulo: Martins Fontes, pp. 95-198, 2006.

DWORKIN, Ronald. Levando os direitos a sério. São Paulo: Martins Fontes, 2002.

DWORKIN, Ronald. O império do Direito. São Paulo: Martins Fontes, 2007.

FERREIRA, Marcelo Ramos Peregrino. O controle de convencionalidade da lei da ficha limpa: direitos políticos e inelegibilidades. Rio de Janeiro: Lumen Juris, 2015.

GABARDO, Emerson. Os perigos do moralismo político e a necessidade de defesa do direito posto na Constituição da República de 1988. A\&C - Revista de Direito Administrativo \& Constitucional, Belo Horizonte, ano 17, n. 70, pp. 65-91, out./dez. 2017.

MACHADO, Igor Suzano. A decisão judicial entre a hermenêutica moral e a articulação política. Revista Brasileira de Estudos Políticos, Belo Horizonte, n. 109, pp. 365-409, jul./dez. 2014.

MÜLLER, Friedrich. Metodologia do Direito Constitucional. Tradução Peter Naumann. São Paulo: Editora Revista dos Tribunais, 2010.

MÜLLER, Jan-Werner. Populist Constitutions - A Contradiction in Terms?, Int'1 J. Const. L. Blog, Apr. 23, 2017, at 
http://www.iconnectblog.com/2017/04/populist-constitutions-a-contradiction-in-terms/

NOVAIS, Jorge Reis. Direitos fundamentais: trunfos contra a maioria. Coimbra: Coimbra ed., 2006.

PAP, András László; ŚLEDZIŃSKA-SIMON, Anna. Mandatory Voting as a Tool to Combat the "New Populism", Int'1 J. Const. L. Blog, Apr. 19, 2017, at: http:/ / www.iconnectblog. com/2017/04/mandatory-voting-and-the-new-populism

RESENDE, Ranieri Lima; VIEIRA, José Ribas. Judicial review e democracia: caminhos para um controle dialógico de constitucionalidade. Revista Brasileira de Estudos Políticos, Belo Horizonte, n. 113, pp. 49-74, jul./ dez. 2016.

REZENDE, Maurício Corrêa de Moura. Democratização do Poder Judiciário no Brasil. São Paulo, Editora Contracorrente, 2018.

SALAZAR UGARTE, Pedro. La democracia constitucional: Una radiografia teórica. México: FCE, II-UNAM, 2006.

SALGADO, Eneida Desiree. Essay on the constitutional promises of democracy and republic. Revista de Investigações Constitucionais, Curitiba, vol. 4, n. 3, pp. 85-100, set./ dez. 2017.

SALGADO, Eneida Desiree. Lei de Acesso à Informação (LAI). Comentário à Lei $\mathrm{n}^{\mathrm{o}} 12.527 / 2011$ e ao Decreto $\mathrm{n}^{\mathrm{o}}$ 7.724/2012. São Paulo: Editora Atlas, 2015.

SÁNCHEZ MORÓN, Miguel. Discrecionalidad Administrativa y Control Judicial. Madrid: Tecnos, 1995.

SARLET, Ingo Wolfgang. A eficácia dos direitos fundamentais: uma teoria geral dos direitos fundamentais na perspectiva constitucional. Porto Alegre: Livraria do Advogado, 2010. 
SCHMITT, Carl. Teología política. Madrid: Editorial Trotta, 2009.

SOUZA, Jessé. A ralé brasileira. São Paulo: Editora Contracorrente, 2017.

TODOROV, Tzvetan. Los enemigos íntimos de la democracia. Barcelona: Galaxia Gutemberg, 2012.

VALIM, Rafael. Estado de exceção: a forma jurídica do neoliberalismo. São Paulo: Editora Contracorrente, 2017.

Recebido em 12/09/2018.

Aprovado em 03/10/2018.

Eneida Desiree Salgado

E-mail: desisalg@gmail.com 
